\title{
Diallyl sulfide inhibits PhIP-induced DNA strand breaks in normal human breast epithelial cells
}

\author{
CHANTELL WILSON, AYOOLA ABOYADE-COLE, ONEIL NEWELL, \\ SELINA DARLING-REED, EBENEZER ORIAKU and RONALD THOMAS \\ Environmental Toxicology Program, College of Pharmacy and Pharmaceutical \\ Sciences, Florida A\&M University, Tallahassee, FL 32307, USA
}

Received March 28, 2006; Accepted May 24, 2006

\begin{abstract}
Heterocyclic amines (HCAs) are formed when meat products such as beef, chicken, pork and fish are cooked at high temperatures. The most abundant HCA found in the human diet is 2-amino-1-methyl-6-phenylimidazo[4,5-b] pyridine (PhIP). PhIP causes mammary carcinomas in female rats and mice, and is associated with an increased risk of developing colon, breast, and prostate cancer in humans. $\mathrm{PhIP}$ is metabolized by cytochrome $\mathrm{P}-450$ s producing $\mathrm{N}-\mathrm{OH}-$ PhIP. The N-OH-PhIP can be esterified by phase II enzymes forming an arylnitrenium ion that binds to DNA causing adducts. Furthermore, N-OH-PhIP may be reduced by cytochrome b5 reductase producing superoxide anions and hydroxyl radicals causing DNA strand breaks. Diallyl sulfide (DAS) has been shown to prevent cancer in several animal models, presumably by metabolic modulation. We hypothesize that PhIP produces reactive oxygen species causing DNA strand breaks and that DAS will inhibit the formation of PhIP induced DNA strand breaks. To test this hypothesis we treated normal breast epithelial (MCF-10A) cells with PhIP, DAS and a combination of PhIP and DAS. The detection of lipid peroxides was used as a surrogate for ROS. Lipid peroxides were detected using a PeroxiDetect kit (Sigma). $\mathrm{PhIP}$ increased the production of lipid peroxides and DAS decreased the PhIP-induced peroxidation by $47 \%$. To determine if PhIP causes DNA strand breaks in MCF-10A cells, cells were treated for 3, 6, 9, and $24 \mathrm{~h}$ with PhIP $(100 \mu \mathrm{M})$, DAS $(100 \mu \mathrm{M})$ and a combination of PhIP $(100 \mu \mathrm{M})$ and DAS $(100 \mu \mathrm{M})$. DNA strand breaks were evaluated using the Comet assay. PhIP produced DNA strand breaks in a dose- and time-dependent fashion. We have shown that DAS inhibits PhIP-induced DNA strand breaks by inhibiting the production of reactive oxygen species. Therefore, we propose that DAS can prevent PhIP-induced breast cancer.
\end{abstract}

Correspondence to: Dr Ronald Thomas, Environmental Toxicology Program, College of Pharmacy and Pharmaceutical Sciences, Florida A\&M University, Tallahassee, FL 32307, USA

E-mail: ronald.thomas@famu.edu

Key words: PhIP, diallyl sulfide, chemoprevention, lipid peroxidation, DNA strand breaks

\section{Introduction}

Heterocyclic amines (HCAs) are formed when meat products such as beef, chicken, pork and fish are cooked at high temperatures. These amines cause colon, breast, and prostate cancer in rats (1) and liver, lung and forestomach cancer in mice (2). Diet is recognized as an important risk factor in the development of human cancers. Epidemiological studies correlate meat intake and cooking practices with an increased risk of breast cancer $(3,4)$.

PhIP (2-amino-1-methyl-6-phenylimidazo[4,5-b] pyridine) at concentrations of $0.1-50 \mathrm{ng} / \mathrm{g}$ of cooked meat, is the most abundant HCA in the human diet $(5,6)$. Furthermore, $\mathrm{PhIP}$ has been shown to produce tumors at multiple sites in both female and male rats and mice (2). While PhIP causes cancer in many species, the proposed mechanism is the same. It has been demonstrated that PhIP is hydroxylated by several cytrochrome P450s (CYP1A1, CYP1A2, CYP1B1) to N-OH$\mathrm{PhIP}(7,8)$. N-OH-PhIP can be conjugated with either a sulfate or acetyl group. The resulting sulfate or acetyl conjugates are unstable and converted to a nutrenium ion that readily binds to DNA generating DNA adducts (9). The N-OH-PhIP can also be reduced by cytochrome b5 resulting in the production of superoxide anions and hydroxyl radicals (10).

Several studies have shown that people in Asian countries have a much lower risk of developing colon, gastrointestinal, prostate and breast cancer compared to their Western counterparts (3). Dietary constituents such as garlic, ginger, soy, tomatoes and green tea play an important role in reducing the rate of cancer (11). Diallyl sulfide (DAS) is a naturally occurring organosulfur compound, which is produced when garlic cloves are processed (12). Metabolic modulation is a key mechanism by which DAS inhibits cancer (13). DAS has been demonstrated to slightly induce the expression of cytochrome P450 2B1/2 (14) and induce the expression of phase II enzymes such as glutathione-Stransferase, UDP-Glucuronosyl transferase and superoxide dismutase $(15,16)$.

We hypothesize that DAS will inhibit the production of reactive oxygen species (ROS) and DNA strand breaks. The inhibition of the production of PhIP-induced DNA strand breaks and ROS by DAS will help elucidate the mechanism by which DAS can prevent PhIP-induced breast cancer. 


\section{Materials and methods}

Cell line, chemicals and reagents. Normal human breast epithelial (MCF-10A) cells were obtained from the American Type Culture Collection (Rockville, MD). Phenol red-free DMEM/F-12 (1:1 mix) media, horse serum, human insulin, epidermal growth factor, cholera toxin, penicillin/ streptomycin, TRIzol, trypsin/EDTA, normal melting point agarose, and low melting point agarose were all obtained from Invitrogen (Carlsbad, CA). Dimethylsulfoxide (DMSO), hydrocortisone, methanol, chloroform, 1\% Triton X-100, PBS, $\mathrm{NaOH}$, Trizma base, $\mathrm{NaCl}, \mathrm{Na}_{2}$ EDTA, ethanol, isopropanol, diethylpyrocarbonate (DEPC), diallyl sulfide (DAS) and the PeroxiDetect kit were purchased from Sigma (St. Louis, MO). Fully frosted microscope slides and cover glass were purchased from Fisher Scientific (Pittsburgh, PA). 2-Amino-1-methyl-6-phenylimidazo[4,5-b]pyridine (PhIP) was purchased from Toronto Research Chemicals (Ontario, Canada).

Cell culture. We chose MCF-10A cells because they represent normal human breast epithelial cells and contain all of the machinery necessary to metabolize PhIP to reactive intermediates $(17,18)$. MCF-10A cells were cultured in $175 \mathrm{~cm}^{2}$ and $25 \mathrm{~cm}^{2}$ flasks containing 1:1 mixure of phenol red-free DMEM/F-12 media supplemented with 5\% horse serum, $10 \mu \mathrm{g} / \mathrm{ml}$ human insulin, $20 \mathrm{ng} / \mathrm{ml}$ epidermal growth factor, $100 \mathrm{ng} / \mathrm{ml}$ cholera toxin, $5 \%$ penicillin/streptomycin and $0.5 \mu \mathrm{g} / \mathrm{ml}$ hydrocortisone. Cells were grown at $37^{\circ} \mathrm{C}$ in a humidified, $95 \%$ air to $5 \% \mathrm{CO}_{2}$ atmosphere. Subculture was performed biweekly using $0.5 \%$ trypsin-EDTA.

Lipid peroxidation. Lipid peroxidation was used as a surrogate for detecting the formation of reactive oxygen species (19). Furthermore, lipid peroxides can cause DNA damage (20). Confluent $175 \mathrm{~cm}^{2}$ flasks of MCF-10A cells were treated with 5, 10, 50, $100 \mu \mathrm{M}$ of PhIP for $24 \mathrm{~h}$ to determine that PhIP causes the production of (ROS). Furthermore, confluent $175 \mathrm{~cm}^{2}$ flasks of MCF-10A cells were treated with 50 and $100 \mu \mathrm{M}$ of DAS in combination with $100 \mu \mathrm{M}$ of PhIP to determine if DAS will prevent the production of lipid peroxides. DMSO $(0.1 \%)$ served as a vehicle control. Cells were removed from the flask using trypsin $(0.5 \%)$ and centrifuged at $800 \mathrm{x}$ g. The pelleted cells were rinsed with $2 \mathrm{ml}$ of cold PBS and pelleted. The pelleted cells were resuspended in $10 \mathrm{ml}$ of methanol/ $\mathrm{H}_{2} \mathrm{O}(2: 0.8)(\mathrm{V}: \mathrm{V})$. To extract the lipids, $3 \mathrm{ml}$ of chloroform was added to the samples and vortexed for $30 \mathrm{sec}$. The samples were allowed to sit at room temperature until the organic and aqueous phases separated (about $5 \mathrm{~min}$ ). The chloroform layer containing the lipids were collected and the samples were extracted a second time with $3 \mathrm{ml}$ of chloroform. The chloroform layers containing the lipids were combined and concentrated by evaporation. A PeroxiDetect kit (Sigma) was used to detect lipid hydroperoxides using a methanolic reagent containing xylenol orange and butylated hydroxytoluene. The oxidized lipids were quantified by measuring the absorption at $560 \mathrm{~nm}$ and compared to a standard curve generated using 0-8 nmoles of butylated hydroxytoluene. The nmoles of peroxides in each of the samples were determined and normalized and expressed as nmoles $/ 10^{6}$ cells.
Statistical analysis. All biochemical measurements were performed in triplicate. Analysis of variance (one-way ANOVA) followed by Tukey's post hoc multiple comparison tests were performed. Significant differences were set at $\mathrm{p}<0.05$.

Comet assay analysis. To determine the extent of DNA strand breaks, cells were cultured in $25 \mathrm{~cm}^{2}$ cell culture flask. Confluent cells were treated with PhIP $(100 \mu \mathrm{M})$, DAS $(100 \mu \mathrm{M})$ and/or a combination of DAS/PhIP $(100 \mu \mathrm{M})$ for $3,6,9$, and $24 \mathrm{~h}$. DMSO (0.1\%) served as a vehicle control. Cells were harvested by treating with trypsin $(0.5 \%)$ for $10 \mathrm{~min}$ and centrifuging at $800 \mathrm{x} \mathrm{g}$. The pelleted cells were suspended in $2 \mathrm{ml}$ of ice cold PBS. One hundred microliters of resuspended cells $(\sim 5,000$ cells $)$ from each treatment was added to $900 \mu \mathrm{l}$ low melting point agarose $(0.75 \%)$. Frosted microscope slides were coated with $100 \mu 1$ normal melting point agarose. These slides were coated with $100 \mu 1$ of low melting point agarose containing treated cells. After solidification on ice, the slides were placed in ice cold lysis buffer (10 mM Tris Base, $100 \mathrm{mM} \mathrm{Na}{ }_{2}$ EDTA, $2.5 \mathrm{M} \mathrm{NaCl}$, and $0.1 \%$ Triton X-100; $\mathrm{pH} 10.0$ ) for $2 \mathrm{~h}$. After lysis, microscope slides were placed in alkaline electrophoresis buffer $(300 \mathrm{mM}$ $\mathrm{NaOH}, 1 \mathrm{mM}$ EDTA; $\mathrm{pH}>13.5$ ) for 30 min to allow the DNA to unwind. After unwinding, the slides were electrophoresed for $30 \mathrm{~min}$ at $280 \mathrm{~A}$ and $25 \mathrm{~V}$ in a cold room at $4^{\circ} \mathrm{C}$. The slides were neutralized with $400 \mathrm{mM}$ Tris buffer $\mathrm{pH} 7.5$ and placed in $100 \%$ ethanol for $5 \mathrm{~min}$ for dehydration. The slides were stained with $100 \mu \mathrm{l}$ of propidium iodide $(20 \mu \mathrm{g} / \mathrm{ml})$. The slides were analyzed using a fluorescent microscope and the Kinetic Imaging Comet assay software. A total of 150 cell images were analyzed per sample using x40 magnification. The mean olive tail moment was the parameter used in this study.

\section{Results}

Lipid peroxidation. To determine if $\mathrm{PhIP}$ produces reactive oxygen species, we treated confluent $175 \mathrm{~cm}^{2}$ flasks of MCF$10 \mathrm{~A}$ cells with PhIP at concentrations of $0,5,10,50$ and $100 \mu \mathrm{M}$ for $24 \mathrm{~h}$. Concentrations of 50 and $100 \mu \mathrm{M}$ of $\mathrm{PhIP}$ produced a dose-dependent increase in lipid peroxides, 50 and 70 nmoles $/ 10^{6}$ cells respectively. There was no significant increase of lipid peroxides at doses of 5 and $10 \mu \mathrm{M}$ (Fig. 1). In order to examine the effects of DAS on PhIP-induced lipid peroxidation, confluent cultures of MCF-10A cells were treated with DAS at concentrations of 50 and $100 \mu \mathrm{M}$ in combination with $\mathrm{PhIP}(100 \mu \mathrm{M})$. Increasing concentrations of DAS (50 and $100 \mu \mathrm{M}$ ) decreased the production of lipid peroxides from $80 \mathrm{nmoles} / 10^{6}$ cells, in PhIP in treated cells to 60 and 46 nmoles $/ 10^{6}$ cells, in cells treated with both $\mathrm{PhIP}$ $(100 \mu \mathrm{M})$ and DAS $(50$ and $100 \mu \mathrm{M})$ respectively. This represents a 33 to $45 \%$ decrease in PhIP-induced lipid peroxidation (Fig. 2). DAS did cause a slight but significant increase in lipid peroxidation. These data demonstrate that DAS can attenuate the production of lipid peroxides in a dose-dependent fashion.

Comet assay analysis. The Comet assay is frequently used to detect DNA strand breaks in individual cells. The mean olive tail moment or simply tail moment is used because it 


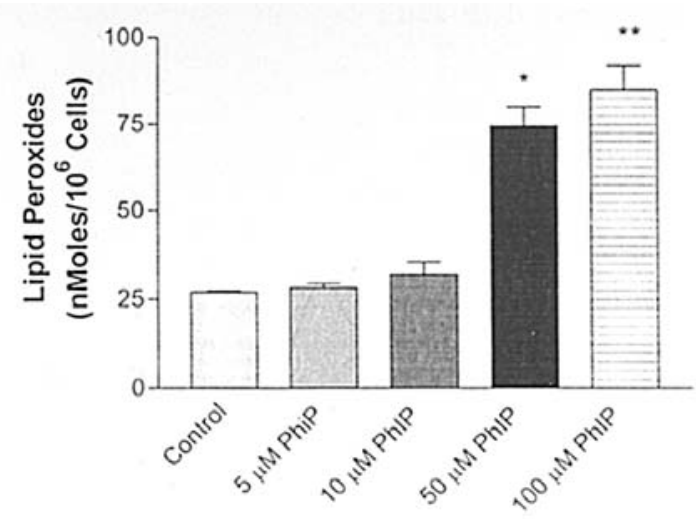

Figure 1. Dose-dependent effects of increasing concentrations of PhIP on lipid peroxidation in MCF-10A cells: $\mathrm{MCF}-10 \mathrm{~A}$ cells were treated with various concentrations of PhIP $(0-100 \mu \mathrm{M})$ for $24 \mathrm{~h}$. Lipids were extracted and lipid peroxides were quantitated. There was no significant change in lipid peroxides at doses of 5 and $10 \mu \mathrm{M}$ of PhIP. At higher doses of PhIP (50 and $100 \mu \mathrm{M}$ ) there was a dose-dependent increase in lipid peroxidation. Results are presented as the mean \pm SE for duplicate measurements from three independent experiments. The single asterisk $\left(^{*}\right)$ indicates values that are significantly different from the control $(\mathrm{p}<0.05)$. The double asterisk (**) indicate values that are significantly different from the $50 \mu \mathrm{M} \mathrm{PhIP}$ treatment $(\mathrm{p}<0.05)$.

incorporates the amount of DNA that has been damaged with the size of the strands. The tail moment is defined as the product of the tail length and the fraction of total DNA in the tail. Tail moment incorporates a measure of both the smallest detectable size of migrating DNA (reflected in the comet tail length) and the number of relaxed/broken pieces; represented by the intensity of DNA in the tail (21). Fig. 3 illustrates DNA strand breaks induced by PhIP $(100 \mu \mathrm{M})$ and the inhibition of PhIP-induced DNA strand breaks by DAS $(100 \mu \mathrm{M})$ in MCF-10A cells. Cells were dosed with PhIP at concentrations of 10,50 and $100 \mu \mathrm{M}$ at $37^{\circ} \mathrm{C}$ for $6 \mathrm{~h}$. PhIP caused a dose-dependent increase in the production of DNA strand breaks, with the average mean olive tail moments being 4, 8, and 13, respectively (Fig. 4). DAS showed a dosedependent decrease in DNA strand breaks in cells treated with $100 \mu \mathrm{M}$ of PhIP and different concentrations of DAS (0, 50 and $100 \mu \mathrm{M})$ the mean olive tail moments being 12.5, 7.5 and 4.0, respectively (Fig. 5). We conducted a time-course experiment to determine the effects of time and DAS on PhIP-induced DNA strand breaks in MCF-10A cells. Cells were dosed with PhIP $(100 \mu \mathrm{M})$, DAS $(100 \mu \mathrm{M})$ and a combination of PhIP and DAS concentration for 3, 6, 9 and $24 \mathrm{~h}$. PhIP-induced DNA strand breaks increased with time from 3 to $9 \mathrm{~h}$, the mean olive tail moment being 5.0,12 and 14 , respectively. At the $24 \mathrm{~h}$ time point, the DNA strand breaks were significantly reduced having a mean olive tail moment of 5.0. At all time points, the DAS decreased the PhIP-induced DNA strand breaks significantly (Fig. 6). We found that DAS reduced the number of DNA strand breaks below the level of the control.

\section{Discussion}

It is generally accepted that the first step in the bioactivation of PhIP (i.e., CYP1A2-catalyzed N-hydroxylation) occurs in the liver. N-OH-PhIP circulates from the liver to the breast

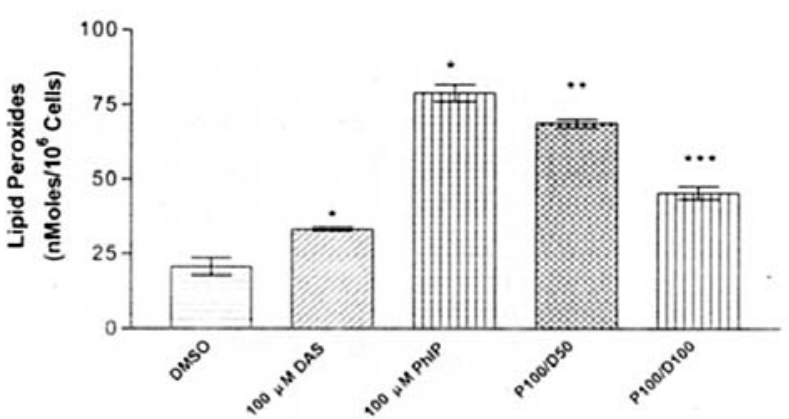

Figure 2. Dose-dependent inhibition of PhIP-induced DNA strand breaks in MCF-10A cells treated with various concentrations of DAS (50-100 $\mu \mathrm{M})$ and $100 \mu \mathrm{M}$ PhIP. Results are presented as the mean \pm SE for duplicate measurements from three independent experiments. The single asterisk $(*)$ indicates values significantly different from the control $(\mathrm{p}<0.05)$. The double asterisk $(* *)$ indicate values significantly different from the PhIP $(100 \mu \mathrm{M})$ treatment $(\mathrm{p}<0.05)$. The triple asterisk $(* * *)$ indicate values significantly different from the PhIP/DAS $(100 \mu \mathrm{M} / 50 \mu \mathrm{M})$ treatment $(\mathrm{p}<0.05)$.

where it can be conjugated with either a sulfate and/or acetyl group. The resulting sulfate or acetate conjugates serve as good leaving groups to generate reactive electrophiles that readily bind to DNA generating DNA adducts (22). These adducts, if not repaired, form mutations which in turn lead to cancer.

Recently, we have demonstrated that cytochrome P450s (CYP1A1, CYP1A2, and CYP1B1) can be induced in MCF$10 \mathrm{~A}$ cells and $\mathrm{PhIP}$ is indeed metabolized in MCF-10A cells to DNA-binding metabolites resulting in the formation of DNA adducts (23) Therefore, we propose that MCF-10A cells metabolize PhIP to N-OH-PhIP via CYP1A1, CYP1A2, and CYP1B1 to N-OH-PhIP which can be reduced to PhIP by cytochrome b5 reductase to produce ROS (10). These ROS lead to DNA strand breaks.

In the current experiments, we have demonstrated that PhIP produces lipid peroxides, which are indicative of the production of ROS in normal breast epithelial cells. An increased production of ROS has been implicated in the induction of cancer, Parkinsons and Alzheimers (24). ROS causes various types of DNA damage including DNA strand breaks and oxidized bases $(20,25)$. Our data suggest that ROS are generated by PhIP which implies that ROS may play a role in PhIP-induced breast cancer.

We have also shown that DAS inhibits PhIP-induced lipid peroxidation. DAS itself causes some lipid peroxidation, however, the mechanism of this is unclear. It is known that DAS is oxidized to diallyl sulfoxide and diallyl sulfone $(26,27)$. We hypothesize that these metabolites may be detected as lipid peroxides. These metabolites do not appear to cause DNA strand breaks because DAS alone, did not cause any strand breaks in this study. Both diallyl sulfoxide and diallyl sulfone have been shown to inhibit the activity of cytochrome $\mathrm{P} 450$ s and presumably cytochrome b5 reductase $(26,27)$. We have previously shown that diallyl sulfide inhibits the redox-cycling of diethylstilbestrol in mammary microsomes, mitochondria and nuclei isolated from female ACI rats (28). Redox cycling is mediated by the oxidation of xenobiotics via cytochrome P450 1A1 and/or 1A2 and 

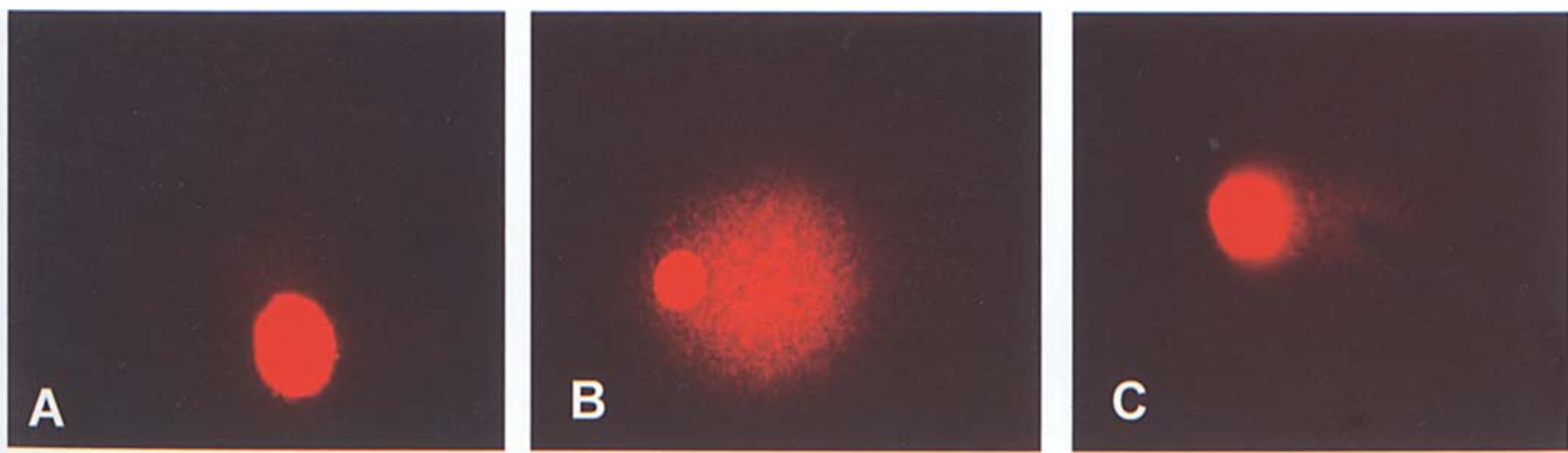

Figure 3. Inhibition of the formation of DNA strand breaks in PhIP-treated MCF-10A cells. Panel A represents a cell that was treated with $0.1 \%$ DMSO as a control. In this cell there are no detectable DNA strand breaks as indicated by the absence of a comet tail. Panel B represents a cell that was treated with PhIP $(100 \mu \mathrm{M})$. In this cell the amount of DNA strand breaks was extensive as indicated by the large comet tail. Panel C represents a cell that was treated with both PhIP and DAS, $100 \mu \mathrm{M}$ each. In this cell DAS inhibited the PhIP-induced DNA strand breaks as indicated by the reduction in the size of the comet tail.

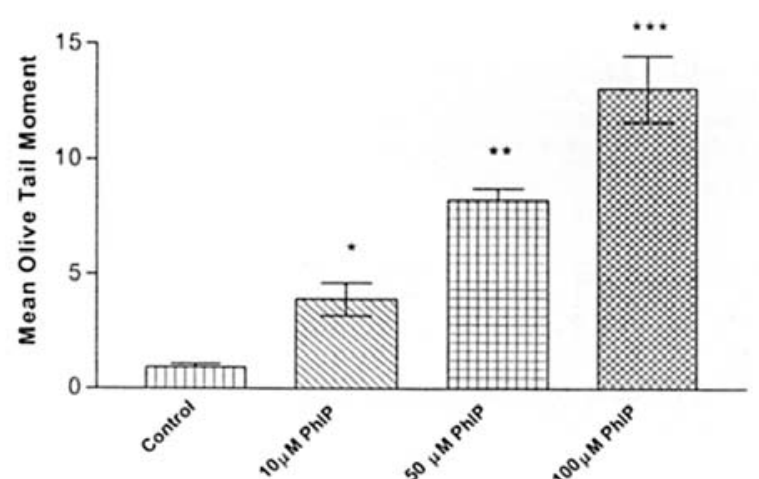

Figure 4. Effect of various concentrations of PhIP (10-100 $\mu \mathrm{M})$ on DNA strand breaks in MCF-10A cells. Increasing concentrations of PhIP results in an increasing production of DNA strand breaks. Results are expressed as the mean olive tail moment \pm SE of 150 cells from three independent experiments. The single asterisk (*) indicates values significantly different from the control $(\mathrm{p}<0.05)$. The double asterisk $(* *)$ indicate values significantly different from the PhIP $(10 \mu \mathrm{M})$ treatment $(\mathrm{p}<0.05)$. The triple asterisk $(* * *)$ indicate values significantly different from the PhIP $(50 \mu \mathrm{M})$ treatment $(\mathrm{p}<0.05)$.

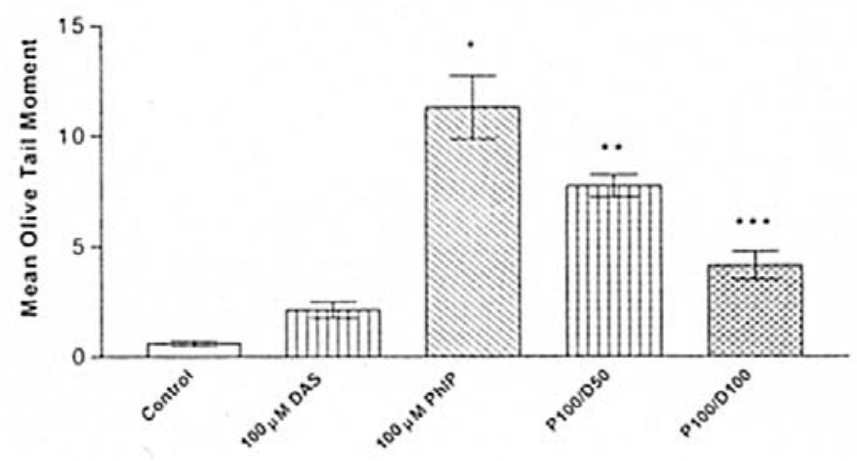

Figure 5. Effect of DAS on PhIP-induced DNA strand breaks in MCF-10A cells after $6 \mathrm{~h}$. MCF-10A cells were treated with $100 \mu \mathrm{M}$ of $\mathrm{PhIP}$ and/or DAS (50 and $100 \mu \mathrm{M}$ ). Dose-dependent decrease in PhIP-induced DNA strand breaks by DAS. The single asterisk (*) indicates values significantly different from the control $(\mathrm{p}<0.05)$. The double asterisk $(* *)$ indicate values significantly different from the PhIP $(100 \mu \mathrm{M})$ treatment $(\mathrm{p}<0.05)$. The triple asterisk $(* * *)$ indicate values significantly different from the PhIP/DAS $(100 \mu \mathrm{M} / 50 \mu \mathrm{M})$ treatment $(\mathrm{p}<0.05)$.

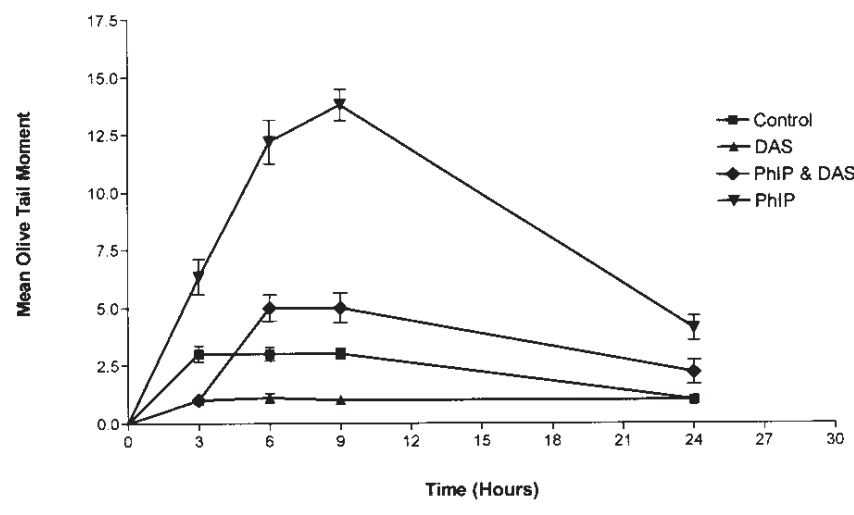

Figure 6. Effect of DAS on PhIP-induced DNA strand breaks in MCF-10A cells after 3-24 h. MCF-10A cells were treated with $100 \mu \mathrm{M}$ PhIP, $100 \mu \mathrm{M}$ DAS, or the $100 \mu \mathrm{M}$ combination of DAS and PhIP for 3-24 h. Results are expressed as mean olive tail moment relative to the control $\pm \mathrm{SE}$ for three independent experiments.

reduction is mediated via cytochrome b5 reductase (10). Therefore, the inhibition of both oxidation and reduction reactions would implicate an inhibition of both cytochrome $\mathrm{P} 450$ s and cytochrome b5 reductase.

We have demonstrated that PhIP $(100 \mu \mathrm{M})$ causes a timedependent increase in the production of DNA strand breaks up to $9 \mathrm{~h}$. This is expected because PhIP is first metabolized to $\mathrm{N}-\mathrm{OH}-\mathrm{PhIP}$ and the reduction of N-OH-PhIP is required to produce the ROS that causes the DNA strand breaks. Previously, we have shown that PhIP induces CYPs (1A1, $1 \mathrm{~A} 2$ and $1 \mathrm{~B} 1)$ in a time-dependent fashion up to $6 \mathrm{~h}$, after which the expression decreases (23). Presumably, the decline in DNA strand breaks at $24 \mathrm{~h}$ occurs due to DNA repair. DAS inhibited the PhIP-induced DNA strand breaks at all time points possibly by inhibiting the cytochrome P450 and cytochrome b5 reductase. Interestingly, DAS inhibited the production of DNA strand breaks below the level of the control. Normal oxidative processes produce ROS that could cause DNA strand breaks (29). This implies that DAS protects DNA from the normal oxidative damage that results from day to day metabolic processes. Furthermore, DAS may 
play a role in preventing the cellular changes related to aging that results from oxidative damage $(30,31)$. DAS has been shown to induce the expression of glutathione $S$ transferase and superoxide dismutase $(15,16)$. The induction of these enzymes may explain why there are fewer strand breaks in the DAS-treated cells compared to the controls.

We have demonstrated for the first time that PhIP significantly causes the formation of lipid peroxides and DNA strand breaks in normal breast epithelial cells, and that the production of lipid peroxides and DNA strand breaks can be attenuated by diallyl sulfide. These data suggest that diallyl sulfide may be used in the chemoprevention of PhIPinduced breast cancer. Further studies are on-going to assess the chemopreventive properties of DAS.

\section{Acknowledgements}

This research was funded in part by NIH Programs RCMI no. G12-RR-03020 and ARCH no. 5 S11ES011182-05.

\section{References}

1. Allen C: A cytogenetic footprint for mammary carcinomas induced by PhIP in rats. Toxicology 182: 95-97, 2002.

2. Shirai T, Imiada K and Ito N: Carcinogenicity in animals and specific organs. Prostate. In: Food-born carcinogens: heterocyclic amines. Nagao M and Sugimura I (eds). Wiley, New York, pp270-274, 2000.

3. Maskarinec G: Breast cancer-interaction between ethnicity and environment. In Vivo 14: 115-123, 2000.

4. Snyderwine EG: Some perspectives on the nutritional aspects of breast cancer research; food-derived heterocyclic amines as etiologic agents in human mammary cancer. Cancer 74 (suppl 3): 1070-1077, 1994.

5. Felton JS, Knize MG, Bennett LM, Malfatti MA, Colvin ME and Kulp KS: Impact of environmental exposures on the mutagenicity/carcinogenicity of heterocyclic amines. Toxicology 198: 135-145, 2004.

6. Norrish AE, Ferguson LR, Knize MG, Felton JS, Sharpe SJ and Jackson RT: Heterocyclic amine content of cooked meat and risk of prostate cancer. J Natl Cancer Inst 91: 2038-2044, 1999.

7. Crofts FG, Sutter TR and Stickland PT: Metabolism of 2amino-1-methyl-6-phenylimidazo[4,5-b]pyridine by human cytochrome P4501A1, P4501A2 and P4501B1. Carcinogenesis 19: 1969-1973, 1998.

8. Williams JA and Phillips DH: Mammary expression of xenobiotic metabolizing enzymes and their potential role in breast cancer. Cancer Res 60: 4067-4677, 2000.

9. Dubuisson JG and Guabatz JW: Bioactivation of the proximal food mutagen 2-hydroxyamino-1-methyl-6-phenylimidazol [4,5] pyridine (N-OH-PhIP) to DNA-binding species by human mammary gland enzymes. Basic Nutrition Investigation 14: 682-686, 1998.

10. Maeda H, Sawa T, Yubisui T and Akaike T: Free radical generation from heterocyclic amines by cytochrome b5 reductase in the presence of NADH. Cancer Lett 14: 117-121, 1999.

11. Edenharder R, Sager JW, Glatt H, Muckel E and Platt KL: Protection by beverages, fruits, vegetables, herbs, and flavonoids against genotoxicity of 2-acetylamainofluorene and 2-amino-1-methyl-6-phenylimidaso[4,5-b]pyridine (PhIP) in metabolically competent V79 cells. Mutat Res 521: 57-72, 2002.

12. Le Bon A, Roy C, Dupont $\mathrm{C}$ and Suschetet M: In vivo antigenotoxic effects of dietary allyl sulfides in the rat. Cancer Lett 114: 131-134, 1997.
13. Guyonnet D, Belloir C, Suschetet M, Siess M and Le Bon A: Mechanisms of protection against aflatoxin $\mathrm{B}(1)$ genotoxicity in rats treated by organosulfur compounds from garlic. Carcinogenesis 23: 1335-1341, 2002.

14. Pan J, Hong JY, Ma BL, Ning SM, Paranawithana SR and Yang CS: Transcripition activation of cytochrome P450 2B1/2 genes in rat liver by diallyl sulfide, a compound derived from garlic. Arch Biochem Biophys 302: 337-342, 1993.

15. SparninsV, Barany G and Wattenberg L: Effects of organosulfur compounds from garlic and onions on benzo(a)pyrene-induced neoplasia and glutathione S-transferase activity in the mouse. Carcinogenesis 9: 131-134, 1988.

16. Guyonnet D, Siess MH, Le Bon AM and Suchetet M: Modulation of phase II enzymes by organosulfur compounds from allium vegetables in rat tissues. Toxicol Appl Pharmacol 154: 50-58, 1999.

17. Falany JL and Falany CN: Expression of cytosolic sulfotransferases in normal mammary epithelial cells and breast cancer cell lines. Cancer Res 56: 1551-1555, 1996.

18. Lewis AJ, Walle UK, King RS, Kadlubar FF, Falany CN and Walle T: Bioactivation of the cooked food mutagen N-OH-2amino-1-methyl-6-phenylimidazo[4,5-b]pyridine by estrogen sulfotransferase in cultured human mammary epithelial cells. Carcinogenesis 19: 2049-2053, 1998.

19. Romero FJ, Bosch-Morell F, Romero MJ, Jareño EJ, Romero B, Marín N and Romá J: Lipid peroxidation products and antioxidants in human disease. Environ Health Perspect 106 (suppl 5): 1229-1234, 1998.

20. Vaca CE, Wilhelm J and Harms-Ringdal M: Interaction of lipid peroxidation products with DNA (Review). Mutat Res 195: 137-149, 1988.

21. Duez P, Dehon G and Dubois J: Validation of raw data measurements in the comet assay. Tanata 63: 879-886, 2004.

22. Snyderwine E, Venugopal M and Yu M: Mammary gland carcinogenesis by food-derived heterocyclic amines and studies on the mechanisms of carcinogenesis of 2-amino-1-methyl-6phenylimidazo[4,5-b]pyridine (PhIP). Mutat Res 506-507: 145-152, 2002.

23. Thomas RD, Green M, Wilson C, Weckle A, Duanmu Z, Kocerak TA and Runge-Morris M: Cytochrome P450 expression and metabolic activation by cooked food mutagen 2amino-1-methyl -6-phenylimidazol [4,5-b]pyridine(PhIP) in MCF10A breast epithelial cells. Chem Biol Interact (In press).

24. Qiao D, Seidler F and Slotkin T: Oxidative mechanisms contributing to the developmental neurotoxicity of nicotine and chlorpyrifos. Toxicol Appl Pharmacol 206: 17-26, 2005.

25. Trush MA and Kensler TW: An overview of the relationship between oxidative stress and chemical carcinogenesis. Free Radic Biol 10: 201-209, 1991.

26. Premdas PD, Bowers RJ and Forkert P: Inactivation of hepatic CYP2E1 by an epoxide of diallyl sulfone. J Pharmacol Exp Ther 293: 1112-1120, 2000.

27. Forkert P, Premdas PD and Bowers RJ: Epoxide formation from diallyl sulfone is associated with CYP2E1 inactivation in murine and human lungs. Am J Respir Cell Mol Biol 23: 687-695, 2000.

28. Thomas R, Green M, Wilson C and Sadrud-Din S: Diallyl sulfide inhibits the oxidation and reduction reactions of stilbene estrogens catalyzed by microsomes, mitochondria, and nuclei from breast of female ACI rats. Carcinogenesis 25: 1-5, 2004.

29. Richter C, Park JW and Ames BN: Normal oxidative damage to mitochondrial and nuclear DNA is extensive. Proc Natl Acad Sci USA 85: 6465-6467, 1988.

30. Murkami S and Murakami H: The effects of aging and oxidative stress on learning behavior in C. Elegans. Neurobiol Aging 26: 809-905, 2005.

31. Martinez G, Loureiro A, Marques S, Miyamoto S, Yamaguchi L, Onuki J, Almeida E, Garcia C, Barbosa L, Medeiros M and Mascio P: Oxidative and alkylating damage in DNA. Mutat Res 544: 115-127, 2003 